\title{
OBITUARY
}

\section{Sir Richard Burn}

By the death, in July 1947, of Sir Richard Burn at the age of 76, Indian scholarship has lost a distinguished student and the Council of this Society a highly valued colleague. Educated at Liverpool Institute and Christ Church, Oxford, he went to India in the Civil Service in 1891. After a few years of life among the people in the Districts, he was taken into the Secretariat of the United Provinces. His natural taste was for the history and archæology of India. Of these he acquired an encyclopædic knowledge, which was given wide scope by his selection to conduct the Census of his Province in 1901, and afterwards to edit the new edition of the Imperial Gazetteer of India. He afterwards held various appointments in the Secretariat. He was, however, very far from being the typical Secretariat Officer, as generally conceived in those days. He never failed to maintain the human touch with both Indians and Europeans. He was greatly relied upon by successive Governors of his Province in the troublous days of increasing nationalistic agitation before, during, and after the first World War. But for the affliction of increasing deafness, he would undoubtedly have risen even higher than he did.

After his retirement in 1926, and his settlement in Oxford, his principal literary work was connected with the Cambridge History of India. He contributed valuable chapters to the third and fourth volumes of that history, besides taking over and completing the editorship of the latter of these volumes, on the death of the previous editor. A similar fatality led to the assumption of the editorship of the second volume, though various circumstances prevented the conclusion of the task.

As a numismatist he was interested from the earliest years of his service in the coinage of India, contributing his first paper on the subject to the Journal of the Royal Asiatic Society in 1897. He was a founder and some time President of the Numismatic Society of India, to whose annual publication he contributed many papers. From 1931 to 1938 he wrote the Note on numismatics for the Annual Bibliography of Indian Archæology. Without being 
a specialist in any period, he had an extensive collection, and was especially skilful in reading Hindu superscriptions.

In comparison with his attainments, his literary output was not great. He was, however, always ready to assist with his learning others who were writing on a great variety of subjects. The exactness of his knowledge made him a very competent reviewer.

To his deafness was latterly added the affliction of failing eyesight. Both defects were alleviated by his astonishing memory and by his unfailing cheerfulness. It was tragic that his end should have come shortly after an operation had given hopes for the recovery of his sight. His judgment was as sound as his knowledge was wide.

By his friends, however, he will be remembered above anything else as a singularly lovable character.

Patrick Cadell. 